\title{
Croatian High-Tech Industry: Current State and Prospects
}

\author{
Gordana DUKIĆ, Goran KOZINA, Darko DUKIĆ
}

\begin{abstract}
The goal of this study is to investigate the current state of Croatian high-tech sector and to evaluate its prospects. The growth of the high-tech sector was greatly impeded by the economic crisis. Despite some progress in recent years, the analysed data suggest that the potential of Croatian high-tech industry has not been sufficiently exploited. The share of high-tech products in Croatian international trades is still low, with imports significantly exceeding exports. For years, the electronics and telecommunications industries have been Croatia's largest high-tech export and import sectors. Lately, the leading high-tech exporter has been the pharmaceutical industry, while the imports and exports of computers and office machines have shown a downward trend. The data also indicate that research and development expenditures have increased substantially over the past several years. However, this is just one of the prerequisites for high-tech industry development. So far, Croatia has not provided an environment that encourages high-tech investments. There are many areas that need improvement for Croatian high-tech sector to become a generator of economic growth, such as creating a positive business and investment climate, stimulating flexible and innovative entrepreneurship, and building an education system capable of meeting the needs of the high-tech industry.
\end{abstract}

Keywords: computers and office machines; Croatian high-tech industry; economic crisis; electronics and telecommunications; research and development

\section{INTRODUCTION}

The high-tech industry plays an important role in contemporary society. It is one of the key development generators in leading global economies. The most developed countries of the world owe their social and economic prosperity largely to investments in advanced technologies and knowledge. In a technology-dominated world, in which information is a vital resource, the hightech industry has rapidly emerged as the main economic activity. Without doubt, its importance will only increase.

Although the term high-tech industry has been used for several decades now, its definition is still a matter of debate in the scientific and professional community. Klincewicz [1] argues that the reason for the lack of consensus on the meaning of the term lies in the various approaches taken to defining it as well as aspects considered, such as the structure of the workforce, the intensity of research and development, or the nature of technology used. As a result, there are inconsistent and sometimes even contradictory opinions as to which industries are high-tech. In defining the term, Klincewicz chose a more restrictive approach according to which high-tech industry encompasses enterprises developing digital technology based on advanced technical knowledge, such as software, hardware and telecommunications. This definition also covers information goods, which are characterized by high initial production costs and low marginal costs of subsequent production. However, the definition includes neither the enterprises that provide biotechnology, engineering and research services nor the high-tech wholesale and retail sector.

Zhou [2] also highlights the lack of consensus on which activities are included in the high-tech industry. According to one of the approaches, the high-tech industry includes sectors based on innovation or highly complex and rapidly-changing technologies. In this context, information technology, telecommunications, biotechnology, medical, pharmaceutical, aerospace and the digital media industry are considered to be high-tech. The problem with such an approach is the fact that traditional production has been rapidly transforming under the influence of the high-tech industry, which sometimes makes it difficult to draw a clear distinction between the two. High-tech industry is also characterised by the significant share of highly-qualified experts and strong focus on research and development, which is a vital factor for corporate competitiveness. Moreover, Zhou underlines the need to look at a specific context when defining the term 'high-tech industry'. For example, the automotive sector is considered to be part of the traditional manufacturing in the developed countries, while in developing countries it is included in the high-tech industry.

According to Tzafrir and Eitam-Meilik [3], the hightech industry is marked by a higher share of engineers and scientists compared to the other sectors. The high-tech industry also allocates a larger share of their budgets to research and development $(R \& D)$ activities than low-tech industries and produces technology-oriented goods and services. Another key feature of the high-tech industry is its potential for exceptionally fast growth. Summing up the conclusions from earlier research studies, Hsieh and Chao [4] identify the following as the most important features of the high-tech industry: technology and capital intensiveness; short life cycle of its products, sizeable market fluctuations and focus on technical specialisation. While in other sectors most workers are not expected to have sophisticated knowledge and skills, the high-tech industry cannot exist without highly educated and competent staff. That is why universities and other higher education institutions are important to the high-tech industry. Namely, they conduct research used in the hightech industry and produce human capital, i.e. highly qualified labour force [5]. This is also why high-tech firms are often located in the vicinity of education and research centres. Krugman, Obstfeld and Melitz [6] remind that the central aspect of an enterprise in the high-tech industry is the generation of knowledge. Such enterprises allocate a significant portion of their resources for research and development, aware of potential initial losses they may suffer in order to gain experience.

Chen [7] points out that the high-tech industry is of national importance for several reasons. The first is that the global market for high-tech products is growing faster than 
other markets, implying that the high-tech industry supports economic growth. Furthermore, innovative hightech firms are seeking to distinguish themselves by creating new markets and/or using resources more productively. In addition, high-tech firms develop numerous value-added products and expand to foreign markets. One should not neglect the fact that other sectors benefit from research and development in the high-tech industry, whereby new products and processes are devised that increase productivity and provide additional employment opportunities.

\section{RESEARCH AIM AND QUESTIONS}

Recognizing the importance of the high-tech industry for economic and social development, the paper aims to investigate the state of Croatian high-tech sector in recent years and assess its potential and prospects. More specifically, the paper seeks to answer the following research questions:

- What have been the trends in Croatian high-tech sector in terms of the number of enterprises and their employees?

- What have been the trends in Croatian high-tech sector in terms of turnover and production value, as well as the imports and exports of high-tech products and services in total and by individual areas?

- What have been the trends in terms of the level of Croatian enterprise R\&D expenditures in high-tech sectors in recent years?

Answering these questions is essential for understanding and assessing the state of Croatian high-tech sector. Moreover, answering them is crucial for an objective assessment of the state of entire Croatian economy and the long-term projection of its development, with the high-tech industry as one of the main drivers. The scarcity of research into these issues makes this study particularly relevant.

\section{RELATED STUDIES}

Numerous scholars and experts worldwide have conducted studies to explore the various issues related to the high-tech industry. This paper looks at the studies in which the development, impact and problems facing the high-tech sector in the EU have been analysed, given that the Republic of Croatia has been a part of that community since 2013.

Lehrer [8] reports on the failures and problems that Germany's high-tech industry faced in seeking to catch up with the US and Japan. He particularly emphasized Germany's lagging behind in the biotechnological development in the 1980s and in the computing industry development during the 1990s. However, German policy makers and researchers in the field of high technology have over time acquired a wealth of experience that has ultimately led to progress. As an example of positive changes, Lehrer mentions a significant increase in venture capital invested in high-tech start-ups. Namely, in the second half of the 1990s, Germany left France and the United Kingdom behind in terms of the level of venture capital investments. For a long time Germany lacked the institutional framework for the development of high-tech entrepreneurship. Universities were not sufficiently focused on creating entrepreneurs inclined to take risks in the field of high technology. Lehrer also finds that German economic system was not flexible enough and failed to facilitate the transformation of traditional industries to new ones that provide greater opportunities. Banks contributed to this situation because they did not have the analytical capacity to assess investments in emerging industries. Despite these problems, Germany was able to strengthen its high-tech sector in the coming period. To determine the factors that contributed to this growth, Klaiber et al. [9] explored German IT, mechanical engineering and construction industries. They chose these industries because of their significant role in the global market and because they were Germany's largest industries in terms of the generated revenue and volume of exports. The strength of German high-tech sector was illustrated using the example of the IT industry, which in 2010 was comprised of 75,000 enterprises and employed almost 926,000 people. That year, the IT industry generated 281.5 billion euro in revenue, an increase of $5.4 \%$ over the previous year. The authors state that the development of German IT industry began in the 1960 s with the establishment of the first computer centres. Computer clusters had a major role in the development of this sector. They were concentrated in several areas, linking enterprises, universities and research institutions. According to the authors, the growth of German IT sector was strongly driven by the demand of enterprises and households for computer systems and software, and supported by customer expectations with regard to meeting the high quality standards and brand image. The authors find that by advocating the digitally networking by information and communication technologies as the driving force of economic growth, German government has contributed to the development of IT industry in the past few years. Similarly, using the Porter's Diamond Model, an analysis was conducted of the state and development of the mechanical engineering and construction industries and it was concluded that a large part of competitive advantages of the high-tech industry was specific to Germany. According to the authors, there were also other factors that had not been covered by the research.

In seeking to identify the determinants of the development of the high-tech manufacturing sector in Poland, Tylżanowski [10] concludes that Poland did not take part in the dynamic development of the high-tech industry, as reflected in the very low share of high-tech products in total sales. He reports the following as possible reasons for the technological gap: the lower competitive capability of Polish products in the global market, reduced productivity of foreign technologies used in Polish industry and excessive consumption of materials, raw materials and energy. The claim that there was a negative trend in the development of Polish high-tech industry was supported by the data indicating that the manufacturing of computers, electronic and optical equipment, as the most important part of the high-tech sector, experienced a drop of almost $5 \%$ in 2011 compared to the previous year, and a reduction in the average employee salary. Tylżanowski points out that in order to achieve long-term and efficient economic growth, Poland must develop its high-tech industry. Michalski [11] explored the competitiveness of Polish mid- 
and high-tech exports in the first decade of the $21^{\text {st }}$ century. The results of his investigation suggest a strong dependence of exports to EU countries on the activities of foreign investors, i.e. multinational enterprises and their technology transfer to Poland. For that reason, the author warns of problems that may arise from such a relationship, such as maintaining low labour costs (wages). Michalski also points to a relatively small number of domestic enterprises that produce sophisticated products with which they can compete in international markets. Although Poland still has the potential to attract foreign investors, the question is how long it will be able to do so. A serious threat in this context is the lack of dynamic research and a development sector capable of bringing innovation and sustainable competitive advantages. Skórska [12] also warned of the inadequate development of Polish high-tech industry and knowledge-intensive services. According to her, the development of the high-tech industry in Poland started much later than in the developed countries. In addition, after 1989, a remarkable decline in the activity of the high-tech sector was recorded not only in Poland, but also in other post-socialist countries. Poor economic policies and often inefficient privatization and restructuring contributed significantly to a decrease in production and the number of employees, and in some areas, caused the disappearance of the high-tech industry. The long-term consequence of such developments is the relatively small share of employees in Polish high-tech sector, especially compared to developed EU countries, and a trade deficit.

Siepel, Cowling and Coad [13] explored the factors that contribute to the long-term growth and survival of UK high-tech enterprises. The results of their research confirm the impact of some widely accepted factors in the academic literature such as innovation investments, entry into international markets and human capital. Among other things, the authors conclude that the early strategic decisions of enterprises have long-run impacts on their survival and growth and that firms' funding environments play key roles in shaping their strategic decisions. The intention of Žitkus and Mickevičienė [14] was to assess the state and prospects of Lithuanian high-tech sector. Based on the conducted analysis, they conclude that the growth of exports and direct foreign investment flows in this sector support the expectations that in the future Lithuanian hightech industry will attain the status it has in the developed countries. However, the authors also pointed to unfavourable conditions for the development of the hightech sector, which is why they believe that radical changes supported by the government need to occur. The research carried out by Šipilova [15] on a sample of Latvian enterprises shows that changes in the technological structure of production for the benefit of the high-tech sector, which were not accompanied by increased labour productivity, do not produce the desired economic effects. On the other hand, less technologically intensive sectors with higher labour productivity can make a more substantial contribution to economic growth. Based on Eurostat data, Constantin [16] conducted an analysis of the high-tech industry in Romania and the European Union. Looking at the period 2006 to 2010, she concludes that after an increase that lasted for two years, total expenses of Romanian high-tech enterprises declined. The data presented by Constantin suggest that the entire period was marked by a drop in the number of employees in Romanian high-tech industry. The decrease in expenses and number of employees was significantly more pronounced in Romania than at the EU level.

\section{RESEARCH METHODOLOGY}

The research is based on Eurostat data. Data on the number of enterprises and employees in the high-tech sector and data on R\&D expenditures are presented in accordance with the Statistical classification of economic activities in the European Community, abbreviated as $N A C E$, while turnover and high-tech imports and exports are presented in accordance with the Standard International Trade Classification, abbreviated as SITC. According to the High-tech aggregation by NACE Rev. 2 [17], high-tech industries are those engaged in the manufacture of basic pharmaceutical products and pharmaceutical preparations and the manufacture of computer, electronic and optical products, while knowledge-intensive high-tech services include motion picture, video and television programme production, sound recording and music publish activities, programming and broadcasting activities, telecommunications, computer programming, consultancy and related activities, information service activities, and scientific research and development. According to the High-tech aggregation by SITC Rev. 4 [18], high-technology trade is defined as exports and imports of the following aggregation products: aerospace, computers and office machines, electronicstelecommunications, pharmacy, scientific instruments, electrical machinery, chemistry, non-electrical machinery, and armament.

\section{ANALYSIS OF INDICATORS AND DISCUSSION}

Tab. 1 shows the number of enterprises in Croatian high-tech sector in the period 2008 to 2014. In addition to the total number, the table contains the number of hightechnology manufacturing enterprises and knowledgeintensive high-tech services, together with indices. The data in Tab. 1 indicate that during the economic crisis there was a decrease in the total number of enterprises in Croatian high-tech sector. The biggest drop was recorded in 2010, when 219 fewer enterprises operated in the sector compared to 2009. The downward trend continued for two years, although to a somewhat lesser extent. Finally, in 2013 and 2014, the number of high-tech enterprises increased. As a result of these changes, in 2014, the number of high-tech enterprises was 10\% higher than in 2008 . During the analysed period, the number of high-tech manufacturing enterprises and knowledge-intensive hightech services did not follow the same trend. Except in 2009, the number of high-tech manufacturing enterprises continually decreased and in 2014, there were 301 fewer companies than in 2008 . Their number fell by more than a third. In the same period, the number of knowledgeintensive high-technology services increased by nearly $19 \%$. The above data point to the vulnerability and exposure of high-tech manufacturing enterprises to changes in the environment, and greater potential for establishing new service enterprises. 


\begin{tabular}{|c|c|c|c|c|c|c|}
\hline Year & Tota* & $\begin{array}{c}\text { High-technology } \\
\text { manufacturing* }\end{array}$ & $\begin{array}{c}\text { Knowledge-intensive } \\
\text { high-technology } \\
\text { services* }\end{array}$ & $\begin{array}{c}\text { Total } \\
(2008=100)\end{array}$ & $\begin{array}{c}\text { High-technology } \\
\text { manufacturing } \\
(2008=100)\end{array}$ & $\begin{array}{c}\text { Knowledge-intensive } \\
\text { high-technology } \\
\text { services } \\
(2008=100)\end{array}$ \\
\hline 2008 & 5372 & 845 & 4527 & 100.0 & 100.0 & 100.0 \\
\hline 2009 & 5904 & 886 & 5018 & 109.9 & 104.9 & 110.8 \\
\hline 2010 & 5685 & 795 & 4890 & 105.8 & 94.1 & 108.0 \\
\hline 2011 & 5660 & 748 & 4912 & 105.4 & 88.5 & 108.5 \\
\hline 2012 & 5645 & 713 & 4932 & 105.1 & 84.4 & 108.9 \\
\hline 2013 & 5753 & 573 & 5180 & 107.1 & 67.8 & 114.4 \\
\hline 2014 & 5927 & 544 & 5383 & 110.3 & 64.4 & 118.9 \\
\hline
\end{tabular}

*Source: Eurostat [19]

The table below shows employment data in Croatian high-tech sector for the period 2008 to 2017 , and the corresponding indices. As in the previous table, the data for high-tech manufacturing enterprises are presented separately from the data on knowledge-intensive hightechnology services. The total number of employees in Croatian high-tech sector increased from 50 thousand in 2008 to 57.1 thousand in 2017 , which represent an increase of $14.2 \%$. The period from 2008 to 2012 was characterized by a $20 \%$ drop in the number of employees. It was not until 2013 that their number began to increase, suggesting that the end of the economic crisis, which affected Croatian high-tech industry, was nearing its end. In the observation period, the number of employees in high-tech manufacturing enterprises fell more than $12 \%$. At the same time, the number of employees in knowledge-intensive high-tech services increased by almost one quarter, which implies that services also have greater potential for employment.

In $2017,3.5 \%$ of all Croatian employees worked in the high-tech sector, compared with $2.8 \%$ in 2008 [20]. This increase is not negligible, but it is also not enough to reach the leading high-tech countries in Europe in near future. According to the same source, in 2017 there were only seven EU countries with a lower percentage of employees in the high-tech sector than in Croatia: Italy (3.4\%), Cyprus $(3.1 \%)$, Poland (3\%), Romania (3\%), Portugal (2.9\%), Greece $(2.5 \%)$ and Lithuania $(2.5 \%)$. On the other side, the Irish high-tech sector employed $8.3 \%$ of all workers. Ireland was followed by Slovenia (5.7\%), Finland (5.7\%), Malta (5.6\%), Estonia (5.5\%), Denmark (5.1\%) and Sweden (5\%).

Table 2 Employment in Croatian high-tech sector

\begin{tabular}{|c|c|c|c|c|c|c|}
\hline Year & $\begin{array}{c}\text { Total* } \\
\text { (thousand) }\end{array}$ & $\begin{array}{c}\text { High-technology } \\
\text { manufacturing* } \\
\text { (thousand) }\end{array}$ & $\begin{array}{c}\text { Knowledge-intensive } \\
\text { high-technology } \\
\text { services* (thousand) }\end{array}$ & $\begin{array}{c}\text { Total } \\
(2008=100)\end{array}$ & $\begin{array}{c}\text { High-technology } \\
\text { manufacturing } \\
(2008=100)\end{array}$ & $\begin{array}{c}\text { Knowledge-intensive } \\
\text { high-technology } \\
\text { services }(2008=100)\end{array}$ \\
\hline 2008 & 50.0 & 13.7 & 36.3 & 100.0 & 100.0 & 100.0 \\
\hline 2009 & 44.7 & 7.9 & 36.8 & 89.4 & 57.7 & 101.4 \\
\hline 2010 & 45.0 & 6.1 & 38.9 & 90.0 & 44.5 & 107.2 \\
\hline 2011 & 44.5 & 7.2 & 37.2 & 89.0 & 52.6 & 102.5 \\
\hline 2012 & 40.0 & 8.5 & 31.4 & 80.0 & 62.0 & 86.5 \\
\hline 2013 & 42.3 & 7.4 & 34.9 & 84.6 & 54.0 & 96.1 \\
\hline 2014 & 48.9 & 10.4 & 38.5 & 97.8 & 75.9 & 106.1 \\
\hline 2015 & 51.9 & 9.8 & 42.2 & 103.8 & 71.5 & 116.3 \\
\hline 2016 & 57.6 & 9.3 & 48.3 & 115.2 & 67.9 & \\
\hline 2017 & 57.1 & 12.0 & 45.0 & 114.2 & 87.6 & 133.1 \\
\hline
\end{tabular}

*Source: Eurostat [20]

Table 3 Economic data on Croatian high-tech sector

\begin{tabular}{|c|c|c|c|c|c|c|}
\hline & \multicolumn{3}{|c|}{$\begin{array}{c}\text { Turnover or gross premiums written } \\
\text { (million euro) }\end{array}$} & \multicolumn{2}{|c|}{$\begin{array}{c}\text { Production value } \\
\text { (million euro) }\end{array}$} \\
\cline { 2 - 7 } Year & Total* & $\begin{array}{c}\text { High-technology } \\
\text { manufacturing* }\end{array}$ & $\begin{array}{c}\text { Knowledge-intensive } \\
\text { high-technology } \\
\text { services* }\end{array}$ & Total* & $\begin{array}{c}\text { High-technology } \\
\text { manufacturing* }\end{array}$ & $\begin{array}{c}\text { Knowledge-intensive } \\
\text { high-technology } \\
\text { services* }\end{array}$ \\
\hline 2011 & 4216 & 893 & 3323 & 3952 & 800 & 3153 \\
\hline 2012 & 4100 & 902 & 3198 & 3799 & 792 & 3007 \\
\hline 2013 & 4289 & 1082 & 3207 & 3995 & 1021 & 2974 \\
\hline 2014 & 4195 & 1126 & 3069 & 3970 & 1051 & 2919 \\
\hline
\end{tabular}

*Source: Eurostat [22]

Tab. 3 contains economic data on Croatian high-tech sector. Eurostat provides data for the period 2011 to 2014 only. In this period, Croatian high-tech industry turnover did not change significantly. However, there are some differences between high-technology manufacturing and knowledge-intensive high-technology services. The turnover of high-technology manufacturing increased, while the turnover of knowledge-intensive hightechnology services decreased. Production value followed the same trend. Taking into account the previously presented data, it can be concluded that between 2011 and
2014 the number of high-technology manufacturing enterprises decreased while the number of employees, as well as turnover and production value increased. In the same period, an increase was recorded in the number of knowledge-intensive high-technology services and the number of employees, while turnover and production value decreased. Data covering a longer period would allow for more relevant conclusions, which is not the case here. It is also not possible to compare turnover and production value of Croatian high-tech sector with those in other EU countries. Such a comparison is possible for personnel 
costs per employee. Personal costs include wages, salaries and social security costs, as well as taxes and other employees' contributions retained by the employer [21]. According to the available data [22], in 2014, average personnel costs in Croatian high-tech industry amounted to 160 thousand euro, which is considerably less than in most other EU countries. For example, in Belgium, France and Austria personnel costs per employee were 648, 572 and 539 thousand euro, respectively. It should be kept in mind that low labour costs affect competitiveness and encourage foreign investment in high-tech industry only when employees are highly skilled and motivated.

The following table presents data on Croatian imports of high-tech products in the period 2007 to 2015 . The table shows data on the imports of computers-office machines, electronics and telecommunications, and pharmacy. The category 'other high-technology industry' includes aerospace, scientific instruments, electrical and nonelectrical machinery, chemistry and armament. Croatian high-tech imports reached their highest level in 2008 when they amounted to 1,650 million euro. High-tech product imports were at their lowest level in 2011. After falling during the economic crisis, high-tech imports began to increase and by 2015 almost reached the 2008 level. During the entire observation period, electronics and telecommunications accounted for the largest share of Croatia's high-tech imports. The strongest growth in the period 2007 to 2015 was recorded in pharmacy imports, while the imports of computers and office machines showed a downward trend.

In the period from 2007 to 2015 , the share of high-tech imports in total Croatian imports did not change to a great extent. In 2007, this percentage was $8.3 \%$, while in 2015 it reached $8.6 \%$ [23]. In most EU countries, the share of hightech imports in total imports is higher than in Croatia, indicating a stronger demand for such products. According to Eurostat [23], in 2015, this percentage was the highest in Ireland $(27.7 \%)$, followed by Luxembourg $(22.6 \%)$, Netherlands (22.6\%), Czech Republic (18.2\%), United Kingdom (17.4\%) and Slovakia (17.1\%). In that year, only six EU countries had a lower share of high-tech imports in total imports than Croatia: Bulgaria $(8.1 \%)$, Greece $(8 \%)$, Portugal (7.7\%), Lithuania (7.5\%), Cyprus (7.3\%) and Slovenia $(7.2 \%)$.

Table 4 Croatian imports of high-tech products

\begin{tabular}{|c|c|c|c|c|c|c|c|c|c|c|}
\hline Year & 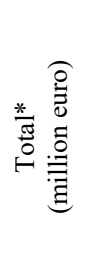 & 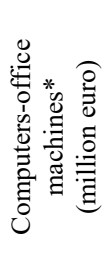 & 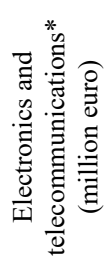 & 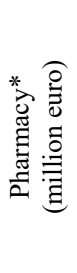 & 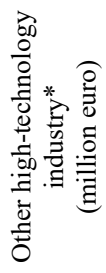 & 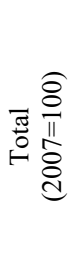 & 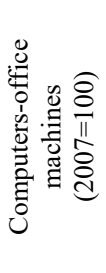 & 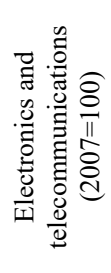 & 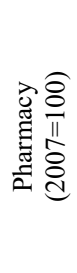 & 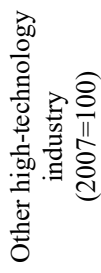 \\
\hline 2007 & 1554 & 343 & 593 & 139 & 479 & 100.0 & 100.0 & 100.0 & 100.0 & 100.0 \\
\hline 2008 & 1650 & 317 & 648 & 165 & 520 & 106.2 & 92.4 & 109.3 & 118.7 & 108.6 \\
\hline 2009 & 1353 & 224 & 503 & 180 & 445 & 87.1 & 65.3 & 84.8 & 129.5 & 92.9 \\
\hline 2010 & 1288 & 227 & 465 & 180 & 416 & 82.9 & 66.2 & 78.4 & 129.5 & 86.8 \\
\hline 2011 & 1229 & 217 & 388 & 194 & 430 & 79.1 & 63.3 & 65.4 & 139.6 & 89.8 \\
\hline 2012 & 1250 & 201 & 426 & 202 & 420 & 80.4 & 58.6 & 71.8 & 145.3 & 87.7 \\
\hline 2013 & 1399 & 225 & 566 & 198 & 410 & 90.0 & 65.6 & 95.4 & 142.4 & 85.6 \\
\hline 2014 & 1346 & 225 & 473 & 236 & 413 & 86.6 & 65.6 & 79.8 & 169.8 & 86.2 \\
\hline 2015 & 1591 & 244 & 573 & 313 & 461 & 102.4 & 71.1 & 96.6 & 225.2 & 96.2 \\
\hline
\end{tabular}

*Source: Eurostat [24]

Table 5 Croatian exports of high-tech products

\begin{tabular}{|c|c|c|c|c|c|c|c|c|c|c|}
\hline Year & 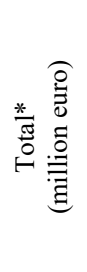 & 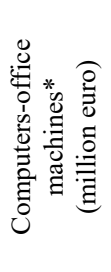 & 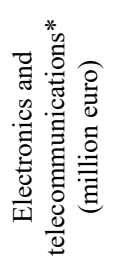 & 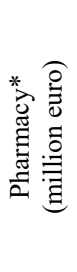 & 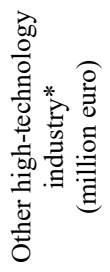 & 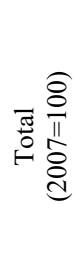 & 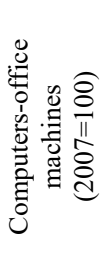 & 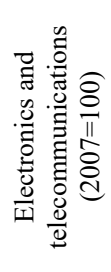 & 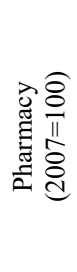 & 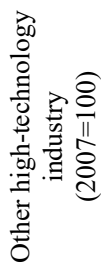 \\
\hline 2007 & 585 & 62 & 187 & 82 & 254 & 100.0 & 100.0 & 100.0 & 100.0 & 100.0 \\
\hline 2008 & 640 & 59 & 207 & 85 & 287 & 109.4 & 95.2 & 110.7 & 103.7 & 113.0 \\
\hline 2009 & 570 & 37 & 180 & 91 & 260 & 97.4 & 59.7 & 96.3 & 111.0 & 102.4 \\
\hline 2010 & 619 & 28 & 178 & 115 & 297 & 105.8 & 45.2 & 95.2 & 140.2 & 116.9 \\
\hline 2011 & 559 & 27 & 145 & 124 & 264 & 95.6 & 43.5 & 77.5 & 151.2 & 103.9 \\
\hline 2012 & 691 & 21 & 200 & 176 & 294 & 118.1 & 33.9 & 107.0 & 214.6 & 115.7 \\
\hline 2013 & 750 & 21 & 241 & 146 & 341 & 128.2 & 33.9 & 128.9 & 178.0 & 134.3 \\
\hline 2014 & 686 & 37 & 164 & 140 & 345 & 117.3 & 59.7 & 87.7 & 170.7 & 135.8 \\
\hline 2015 & 824 & 45 & 215 & 227 & 337 & 140.9 & 72.6 & 115.0 & 276.8 & 132.7 \\
\hline
\end{tabular}

*Source: Eurostat [24]

Tab. 5 shows data on Croatian exports of high-tech products for the period 2007 to 2015 . As in the previous table, the data on exports are presented separately for computers and office machines, electronics and telecommunications, and pharmacy. In the period from
2007 to 2015, Croatian exports of high-tech products increased significantly. Despite this, the imports of hightech products were still almost two times larger than the exports in 2015. By 2015, the biggest contribution to Croatian high-tech exports was made by the electronics and 
telecommunications industry. In the last year of the observation period, the pharmaceutical industry was the largest contributor to Croatian exports. In contrast to pharmaceutical products, the exports of computers and office machines dropped significantly.

The share of high-tech exports in total Croatian exports were slightly increased during the analysed period. In 2007, high-tech products made up $6.5 \%$ of all Croatian exports. Eight years later, in 2015, the share of high-tech exports in total Croatian exports reached 7.1\% [23]. Although some progress has been made, Croatia still lags behind most other EU countries. According to Eurostat [23], in 2015, Malta was placed at the top of the list of EU countries with the highest share of high-tech exports in total exports $(24.2 \%)$. Malta was followed by Ireland (24\%), France $(21.6 \%)$, Netherlands $(20 \%)$, Luxemburg (19.7\%) and Cyprus (19.3\%). In 2015, there were seven EU countries with a lower percentage of high-tech exports in total exports than in Croatia: Finland (7\%), Italy $(6.9 \%)$, Slovenia (5.9\%), Spain (5.4\%), Bulgaria (4.6\%), Greece $(4.6 \%)$ and Portugal $(3.8 \%)$. Here, it should be noted that Germany is the EU leader in high-tech trade for many years. In 2015, France was the second largest high-tech exporter with a positive balance of trade, ahead of Netherlands and Ireland [23].

The table below contains data on Croatian business enterprise $R \& D$ expenditure in high-tech sectors for the period 2005 to 2014.

Table 6 Croatian business enterprise R\&D expenditure in high-tech sectors

\begin{tabular}{|c|c|c|}
\hline Year & $\begin{array}{c}\text { R\&D expenditure* } \\
\text { (million euro) }\end{array}$ & $\begin{array}{c}\text { R\&D expenditure } \\
(2005=100)\end{array}$ \\
\hline 2005 & 6 & 100.0 \\
\hline 2006 & 7 & 116.7 \\
\hline 2007 & 8 & 133.3 \\
\hline 2008 & 52 & 866.7 \\
\hline 2009 & 25 & 416.7 \\
\hline 2010 & 28 & 466.7 \\
\hline 2011 & 30 & 500.0 \\
\hline 2012 & 36 & 600.0 \\
\hline 2013 & 42 & 700.0 \\
\hline 2014 & 49 & 816.7 \\
\hline
\end{tabular}

*Source: Eurostat [25]

In the course of 2005, 2006 and 2007, Croatian business enterprise R\&D expenditure in high-tech sectors was very small. The biggest increase in $\mathrm{R} \& \mathrm{D}$ expenditure occurred in 2008. However, the expenditure more than halved the following year. Although it was later increased, by 2014, it did not reach the level recorded in 2008 . Generally, it can be concluded that there was a positive trend that slowed down due to the economic crisis. In 2014, Croatia spent more for R\&D than Romania, Lithuania, Bulgaria, Slovakia, Latvia, Estonia, Malta and Cyprus [25], but this is still not enough to ensure the long-term development of high-tech industry.

\section{CONCLUSION}

In contemporary society, the high-tech industry is a vital driver of development. However, the potential of high-tech industry in Croatia is largely untapped. Still, it would be wrong to conclude that in recent years no progress was made in the development of Croatian hightech sector. Its development was severely inhibited during the economic crisis, which hit Croatia somewhat later than other countries and lasted a little longer. The data presented in this paper indicate that Croatian high-tech industry started to grow after the crisis had ended. The new circumstances allowed for an increase in the total number of enterprises and employees as well as increased exports of high-tech products. But while the number of knowledgeintensive high-tech services and their employees rose, the number of high-tech manufacturing enterprises and their workers declined. The available data suggest that electronics and telecommunications industries had been the largest exporters and importers of high-tech products for years. Recently, they have been replaced by the pharmaceutical industry. The presented data also show that the imports and exports of computers-office machines during the analysed period had a downward trend. It is encouraging to note that research and development expenditure in the Croatian high-tech sector was continually increasing in recent years, which is one of the main preconditions for progress.

There are several conditions that need to be met in order for the high-tech industry to develop. In this context, the question arises as to the prospects of Croatian economy. To achieve long-term growth of the high-tech sector, the government must establish a stable legal and institutional framework that will attract foreign investors, especially in high-tech areas that require large investments. It is also clear that government institutions must be efficient, transparent and at the service of entrepreneurs. Despite some positive changes, Croatia has not positioned itself as a desirable high-tech investment destination. Inconsistent legislation, high tax burden, and cumbersome and inefficient public administration are some of the factors often identified as reasons for the lack of competitiveness of Croatian economy. In addition, the government must stimulate high-tech investments through various measures. Since the high-tech industry requires highly-qualified employees, it is very important to build an education system that will provide the business sector with the required workforce profile. This has not been the case so far, resulting in a shortage of experts in many high-tech areas and a surplus of inadequately qualified staff in the labour market. Since its accession to the European Union, Croatia has been facing one more problem. A number of Croatian high-tech professionals have decided to leave the country, which has further aggravated the shortage of hightech staff.

Although the high-tech industry is often associated with significant financial investments, there are areas where noticeable improvement can be made even without substantial resources. A good example of this is the software industry; however, this is another sector where the lack of developers and other IT professionals has impeded greater progress. Considering the importance of an industry being based on advanced technologies, it is high time to intensify the development of Croatian high-tech sector. Creating flexible and innovative entrepreneurship should be the first step towards ensuring a stable and sustainable high-tech industry in the long run. If it continues to lag behind, Croatia's chances to join the world's leading economies will be further compromised. Based on the data presented in this paper, it can be concluded that Croatian high-tech industry has the 
potential for growth, but that it will take a series of carefully designed activities at national and local levels for that potential to be realised.

\section{REFERENCES}

[1] Klincewicz, K. (2005). Strategic alliances in the high-tech industry. Berlin: Logos Verlag.

[2] Zhou, Y. (2009). High-tech industry. In R. Kitchin \& N. Thrift (Eds.). International encyclopedia of human geography (Vol. 5, pp. 122-127). Amsterdam: Elsevier. https://doi.org/10.1016/B978-008044910-4.00171-1

[3] Tzafrir, S. S. \& Eitam-Meilik, M. (2005). The impact of downsizing on trust and employee practices in high tech firms: A longitudinal analysis. The Journal of High Technology Management Research, 16(2), 193-207. https://doi.org/10.1016/j.hitech.2005.10.008

[4] Hsieh, A.-T. \& Chao, H.-Y. (2004). A reassessment of the relationship between job specialization, job rotation and job burnout: Example of Taiwan's high-technology industry. The International Journal of Human Resource Management, 15(6), 1108-1123. https://doi.org/10.1080/09585190410001677331

[5] Goetz S. J. \& Rupasingha, A. (2002). High-tech firm clustering: Implications for rural areas. American Journal of Agricultural Economics, 84(5), 1229-1236. https://doi.org/10.1111/1467-8276.00383

[6] Krugman, P. R., Obstfeld, M., \& Melitz, M. J. (2018). International economics: Theory and policy (11 ${ }^{\text {th }}$ ed.). Harlow: Pearson.

[7] Chen, Y.-M. (2008). How much does country matter? The estimation of variance in high-tech industry performance. International Regional Science Review, 31(4), 404-435. https://doi.org/10.1177/0160017608321447

[8] Lehrer, M. (2000). Has Germany finally fixed its high-tech problem? The recent boom in German technology-based entrepreneurship. California Management Review, 42(4), 89-107. https://doi.org/10.2307/41166055

[9] Klaiber, T., Huber, M., Schwehr, M., \& Rittippant, N. (2013). An investigation of German high-technology industries. In Proceedings of the $4^{\text {th }}$ International Conference on Engineering, Project, and Production Management (EPPM 2013), October 23-25, 2013, Bangkok, 743-758. https://doi.org/10.32738/CEPPM.201310.0067

[10] Tylżanowski, R. (2012). Determinants of development of the high-tech manufacturing sector in Poland. Zeszyty Naukowe Uniwersytetu Szczecińskiego. Studiai Prace Wydzialu Nauk Ekonomicznychi Zarzadzania, 29, 195-208.

[11] Michalski, B. (2014). Competitiveness of Polish mid-tech and high-tech exports to the European Union (EU-27) in the first decade of the $21^{\text {st }}$ century. The Poznan University of Economics Review, 14(4), 54-70.

[12] Skórska, A. (2016). High-tech industry and knowledge intensive services as carriers of knowledge-based economy in Poland and in other European Union member states. Folia Pomeranae Universitatis Technologiae Stetinensis. Oeconomica, 85(4), 137-146. https://doi.org/10.21005/oe.2016.85.4.14

[13] Siepel, J., Cowling, M., \& Coad, A. (2012). Long-run growth and survival of UK high technology firms. Nesta Working Paper, No. 12/13. Retrieved from http://www.nesta.org.uk/ sites/default/files/long run growth and survival of uk hi gh_technology_firms_12-13_final.pdf

[14] Žitkus, L. \& Mickevičienè, M. (2008). High-tech sector in Lithuania: present situation and future perspectives. European Integration Studies, 2, 98-107.

[15] Šipilova, V. (2015). When regional growth does not benefit from high-tech specialization? Explaining the experience of
Latvian regions. Procedia Economics and Finance, 30, 863875. https://doi.org/10.1016/S2212-5671(15)01336-2

[16] Constantin, S. (2012). Analysis of high-tech companies evolution indicators in Romania and in the European Union. Bulletin of the Transilvania University of Braşov. Series V: Economic Sciences, 5(2), 95-100.

[17] Eurostat (n.d.). Annex 3 - High-tech aggregation by NACE Rev. 2. Retrieved from http://ec.europa.eu/eurostat/cache/ metadata/Annexes/htec_esms_an3.pdf

[18] Eurostat (n.d.). Annex 5 - High-tech aggregation by SITC Rev. 4. Retrieved from http://ec.europa.eu/eurostat/cache/ metadata/Annexes/htec_esms_an5.pdf

[19] Eurostat (2016). Enterprises in high-tech sectors by NACE Rev. 2 activity. Retrieved from http://appsso.eurostat.ec.europa.eu/nui/show.do?dataset=hte c_eco_ent2\&lang=en

[20] Eurostat (2018). Employment in technology and knowledgeintensive sectors at the national level, by sex (from 2008 onwards, NACE Rev. 2). Retrieved from $\mathrm{http} / / /$ appsso.eurostat.ec.europa.eu/nui/show.do?dataset=hte c_emp_nat $2 \&$ lang $=$ en

[21] Eurostat (2012). Glossary: Personnel costs - SBS. Retrieved from http://ec.europa.eu/eurostat/statistics-explained/ index.php/Glossary:Personnel_costs_-_SBS

[22] Eurostat (2016). Economic data in high-tech sectors by NACE Rev. 2 activity. Retrieved from http://appsso.eurostat.ec.europa.eu/nui/show.do?dataset=hte c_eco_sbs2\&lang=en

[23] Eurostat (2016).Total high-tech trade in million euro and as a percentage of total (from 2007, SITC Rev. 4). Retrieved from http://appsso.eurostat.ec.europa.eu/nui/show.do? dataset $=$ htec_trd tot $4 \&$ lang $=$ en

[24] Eurostat (2016). High-tech trade by high-tech group of products in million euro (from 2007, SITC Rev. 4). Retrieved from http://appsso.eurostat.ec.europa.eu/nui/ show.do?dataset $=$ htec_trd_group4\&lang $=$ en

[25] Eurostat (2017). Business enterprise R\&D expenditure in high-tech sectors - NACE Rev. 2. Retrieved from http://appsso.eurostat.ec.europa.eu/nui/show.do?dataset=hte c_sti_exp2\&lang=en

\section{Contact information:}

Gordana DUKIĆ, PhD, Associate Professor Josip Juraj Strossmayer University of Osijek Faculty of Humanities and Social Sciences, Department of Information Sciences,

Lorenza Jägera 9, 31000 Osijek, Croatia

E-mail: gdukic@ffos.hr

Goran KOZINA, PhD, Associate Professor University North in Varaždin, 104. brigade 3, 42000 Varaždin, Croatia E-mail: goran.kozina@unin.hr

Darko DUKIĆ, PhD, Full Professor Josip Juraj Strossmayer University of Osijek, Department of Physics,

Trg Ljudevita Gaja 6, 31000 Osijek, Croatia

E-mail: darko.dukic@fizika.unios.hr 